\title{
Hippocampal Neurons Express a Calcineurin-Activated Adenylyl Cyclase
}

\author{
Guy C.-K. Chan, ${ }^{1}$ Susumu Tonegawa, ${ }^{2}$ and Daniel R. Storm ${ }^{1}$ \\ ${ }^{1}$ Department of Pharmacology, University of Washington, Seattle, Washington 98195, and ${ }^{2}$ Howard Hughes Medical Institute, The Picower Center for \\ Learning and Memory and RIKEN/Massachusetts Institute of Technology Neuroscience Research Center, Departments of Biology and Brain and Cognitive \\ Sciences, Massachusetts Institute of Technology, Cambridge, Massachusetts 02139
}

\begin{abstract}
$\mathrm{Ca}^{2+}$-stimulated adenylyl cyclases are important for several forms of neuroplasticity because they couple activity-dependent $\mathrm{Ca}^{2+}$ increases to CAMP in neurons. For example, the calmodulin-stimulated adenylyl cyclases, AC1 and AC8, are required for hippocampusdependent memory and long-lasting long-term potentiation. To identify other mechanisms for $\mathrm{Ca}^{2+}$ stimulation of adenylyl cyclases, cultured hippocampal neurons from transgenic mice lacking both AC1 and AC8 [double knock-out (DKO) mice] were analyzed for Ca ${ }^{2+}$ stimulation of intracellular cAMP. Surprisingly, neurons from DKO mice showed significant $\mathrm{Ca}^{2+}$-stimulated cAMP accumulation that was blocked by inhibitors of calcineurin [PP2B (protein phosphatase $2 \mathrm{~B}$ )], a $\mathrm{Ca}^{2+}$-activated protein phosphatase. Analysis of cultured neurons from calcineurin ${ }^{-I-}$ mice confirmed that hippocampal neurons exhibit a calcineurin-dependent cAMP increase, which may contribute to some forms of neuroplasticity.
\end{abstract}

Key words: adenylate cyclase; knock-out mice; hippocampus; phosphatase; calcium; signal transduction

\section{Introduction}

The cAMP signal transduction pathway is critical for several types of neuroplasticity including long-term potentiation (LTP) and long-term memory (LTM) formation (Poser and Storm, 2001; Wang and Storm, 2003). For example, cAMP-mediated transcription is required for long-lasting LTP (L-LTP) in area CA1, mossy fiber, and the medial perforant pathways (Frey et al., 1991, 1993; Impey et al., 1996; Nguyen and Kandel, 1996; Abel et al., 1997). A role for cAMP in LTP and hippocampus-dependent memory is strongly supported by transgenic mouse studies in which the genes for components of the cAMP signal transduction pathway have been disrupted. Disruption of the genes for $\mathrm{C} 1 \beta$ or RI $\beta$ subunits of cAMP-dependent protein kinase A (PKA) abates mossy fiber LTP (Huang et al., 1995). Mice deficient in the type I adenylyl cyclase (AC1) are deficient in spatial memory (Wu et al., 1995), mossy fiber LTP (Villacres et al., 1998), and cerebellar LTP (Storm et al., 1998), whereas mice lacking both AC1 and AC8 [double knock-out (DKO)] exhibit no LTM or L-LTP (Wong et al., 1999). Furthermore, a genetic increase in AC1 in the forebrain of mice enhances LTP as well as memory for novel objects (Wang et al., 2004). The critical role played by the calmodulin (CaM)stimulated adenylyl cyclases for LTP and memory emphasizes the physiological importance of coupling $\mathrm{Ca}^{2+}$ increases to cAMP in CNS neurons.

To date, clones for 10 adenylyl cyclases have been isolated,

Received June 9, 2005; revised Sept. 13, 2005; accepted Sept. 15, 2005.

This study was supported by National Institutes of Health Grants NS37056 and NS20498 (D.R.S.), as well as P50-MH58880 (S.T.).

Correspondence should be addressed to Daniel R. Storm, Department of Pharmacology, University of Washington, Seattle, WA 98195. E-mail: dstorm@u.washington.edu.

DOI:10.1523/JNEUROSCI.2376-05.2005

Copyright $\odot 2005$ Society for Neuroscience $\quad$ 0270-6474/05/259913-06\$15.00/0 each with unique regulatory properties (Hanoune and Defer, 2001); nine are expressed in the hippocampus. There are several mechanisms for $\mathrm{Ca}^{2+}$ stimulation of adenylyl cyclases in neurons including $\mathrm{Ca}^{2+}$ activation of the CaM-stimulated adenylyl cyclases, AC1 and AC8. Other potential mechanisms include modulation by protein kinases or protein phosphatases. For example, protein kinase $\mathrm{C}$ (PKC) stimulates the activities of several cyclases, including AC2 and AC3, which are expressed in the hippocampus (Choi et al., 1993; Jacobowitz et al., 1993; Kawabe et al., 1996). The contribution of these mechanisms to $\mathrm{Ca}^{2+}$-stimulated cAMP increases in neurons has been difficult to evaluate because of the presence of substantial levels of CaM-stimulated adenylyl cyclase activity in CNS neurons (Wong et al., 1999).

Membranes isolated from the brains of DKO mice show no $\mathrm{Ca}^{2+} / \mathrm{CaM}$-stimulated adenylyl cyclase, indicating that $\mathrm{AC} 1$ and AC8 are the only adenylyl cyclases in the brain that are directly regulated by CaM. However, assay of adenylyl cyclase activity in membranes would not reveal $\mathrm{Ca}^{2+}$ activation mechanisms that depend on soluble proteins lost during membrane isolation. In this study, cultured hippocampal neurons from DKO mice were analyzed for $\mathrm{Ca}^{2+}$ stimulation of cAMP accumulation in vivo using depolarizing agents or NMDA to increase intracellular $\mathrm{Ca}^{2+}$. Surprisingly, cultured hippocampal neurons from DKO mice show only a partial reduction in $\mathrm{Ca}^{2+}$ stimulation of intracellular cAMP. Our analysis indicates that a significant fraction of the $\mathrm{Ca}^{2+}$-stimulated cAMP accumulation in hippocampal neurons depends on the $\mathrm{Ca}^{2+}$-stimulated protein phosphatase calcineurin. This suggests the interesting possibility that one of the reasons that calcineurin ${ }^{-1-}$ mice show defects in some forms of synaptic plasticity may be loss of calcineurin-mediated cAMP increases. 


\section{Materials and Methods}

Transgenic mouse strains. DKO and calcineurin $^{-1-}$ bred into a C57BL/6 background for eight generations were generated as described previously (Wong et al., 1999; Zeng et al., 2001). Wild-type littermates were used as controls.

Primary hippocampal neuron cultures. Primary neurons from the hippocampus were prepared as described previously (Chan et al., 2001) from postnatal day 1 mouse pups of wildtype or DKO mice with the following modifications. Neurons were plated into 48 -well plates at cell densities between 5 and $10 \times 10^{4}$ cells per well in Neurobasal medium supplemented with $1 \%$ penicillin-streptomycin, $0.5 \mathrm{~mm}$ glutamine, $1 \times \mathrm{B}-27$ supplements, $0.5-1.0 \%$ fetal bovine serum (all from Invitrogen, Carlsbad, CA) and $20 \mu \mathrm{M}$ glutamate. Cytosine $\beta$-D-arabinofuranoside (Sigma, St. Louis, MO) was added $1-2 \mathrm{~d}$ after initial plating at $5 \mu \mathrm{M}$ to inhibit proliferating cell growth. Every 5-6 d after plating, one-third of the media was replaced with fresh media without additional glutamate or cytosine $\beta$-D-arabinofuranoside. cAMP accumulation assays were performed $14 \mathrm{~d}$ after initial plating. Neurons from calcineurin/protein phosphatase 2B (PP2B) regulatory subunit knock-out pups (Zeng et al., 2001) were prepared as described above, except that no glutamate was added at initial plating and cultures were assayed from 12-14 d in vitro.

cAMP accumulation and adenylyl cyclase assays. The day before assaying, neurons were treated overnight with $3 \mu \mathrm{Ci} / \mathrm{ml}$ of $2,8-{ }^{3} \mathrm{H}$ adenine (PerkinElmer Life Sciences, Boston, MA). Sixteen to $24 \mathrm{~h}$ later, the media were completely aspirated, and neurons were incubated in Neurobasal medium in the presence of $1 \mu \mathrm{M}$ 3-isobutyl-1-methylxanthine (Sigma) in a $\mathrm{CO}_{2}$ incubator for at least $45 \mathrm{~min}$. $\mathrm{KCl}$ stimulation of neurons were initiated in Neurobasal medium in a final volume of $500 \mu \mathrm{l}$ for $10 \mathrm{~min}$ at $25^{\circ} \mathrm{C}$ and stopped by the addition of $5 \%$ trichloroacetic acid containing $1.0 \mu \mathrm{M}$ cAMP. cAMP accumulation was determined as described previously (Salomon, 1991) and reported as the fraction of cAMP relative to total nucleotides (cAMP plus AMP plus ADP plus ATP). Where indicated, an additional incubation step for 45-75 min with various inhibitors or other reagents was added before $\mathrm{KCl}$ stimulation. Results are reported as the mean from triplicate determinations $\pm \mathrm{SD}$ with multiple repeats. Adenylyl cyclase activity in membrane preparations from wild-type and transgenic mice was determined, analyzed, and interpreted as described previously (Wong et al., 1999). Where appropriate, we used BCA assay (Pierce, Rockford, IL) to determine protein concentrations.

Reagents and inhibitors. Unless otherwise stated, all general chemicals and reagents were purchased from Sigma. Reagents for tissue culturing were from Invitrogen. Ascomycin, 3-bromo 7-nitroindazole, cantharidin, cyclosporine A, endothall, Go 6976, Jun kinase inhibitor II, NMDA, okadaic acid, PD98059 [2-(2-amino-3-methyoxyphenyl)-4H-1-benzopyran-4-one], Rp-8-Br-cAMPS, SB203580 [4-(4-fluorophenyl)-2-(4-methylsulfonylphenyl)-5-(4-pyridyl)- $1 \mathrm{H}$ imidazole], and U0126 [1,4-diamino-2,3-dicyano-1,4-bis(o-aminophenylmercapto)butadiene] were purchased from Calbiochem (La Jolla, CA). Phorbol 12-myristate 13-acetate was from Tocris Cookson (Ellisville, MO). Kynurenic acid was from Sigma. Go 6983, L-N-nitroarginine methyl ester $\mathrm{HCl}$ (L-NAME), myristoylated-AIP (autocamtide-2-related inhibitory peptide) calcium/calmodulindependent kinase II (CAMK II) inhibitor, and thapsigargin were from Biomol (Plymouth Meeting, PA). SB202190 [4-(4-fluorophenyl)-2(4-hydroxyphenyl)-5-(4-pyridyl) $1 \mathrm{H}$-imidazole] and staurosporine were from Tocris Cookson, Biomol, or Calbiochem. 2-Amino-5phosphonovaleric acid (D-APV) was from Biomol or Calbiochem.

Statistical analysis. Statistical significance was established by one-way ANOVA and Student's $t$ test.

\section{B. Hippocampal Neurons}

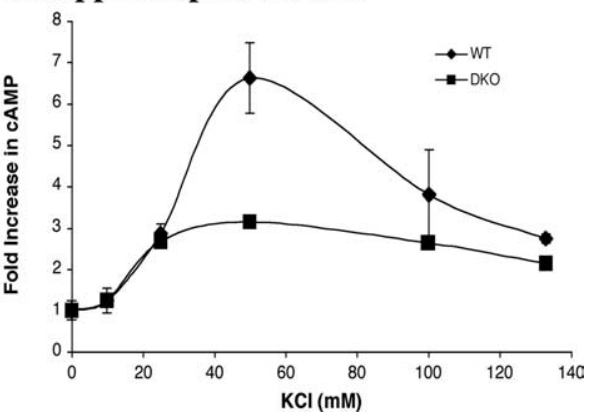

Figure 1. Cultured hippocampal neurons from DKO mice exhibit KCl-stimulated cAMP increases. $\boldsymbol{A}$, Membrane assays. Adenylyl treated with various concentrations of $\mathrm{KCl}$ as indicated. The accumulation of intracellular cAMP was performed as described in Materials and Methods. Data are mean \pm SD of triplicates.

\section{Results}

\section{Intracellular $\mathrm{Ca}^{2+}$ increases cAMP in cultured hippocampal neurons from DKO mice}

Membranes isolated from the hippocampus of DKO mice show no measurable $\mathrm{Ca}^{2+} / \mathrm{CaM}$-stimulated adenylyl cyclase (Fig. $1 \mathrm{~A}$ ), indicating that hippocampal neurons express only two CaMactivated adenylyl cyclases, AC1 and AC8. In addition, there are no compensating increases in other adenylyl cyclases in DKO hippocampal membranes to accommodate for the loss of CaMstimulated adenylyl cyclase activity.

Because signaling mechanisms that depend on soluble, cytosolic components may be compromised during membrane isolation, we examined intact cultured hippocampal neurons for $\mathrm{Ca}^{2+}$ stimulation of cAMP accumulation using $\mathrm{KCl}$ depolarization to increase intracellular $\mathrm{Ca}^{2+}$. These experiments were performed in high concentrations of cAMP phosphodiesterase (PDE) inhibitors to block changes in intracellular cAMP caused by PDEs. Intracellular cAMP in cultured hippocampal neurons from wild-type (WT) mice was stimulated 6.5 -fold by $50 \mathrm{~mm} \mathrm{KCl}$ (Fig. 1 B). Surprisingly, $\mathrm{KCl}$ caused a significant increase in intracellular cAMP in DKO neurons with a stimulation of approximately threefold.

To confirm that the $\mathrm{KCl}$ stimulation of cAMP increases in neurons cultured from DKO mice is attributable to membrane depolarization and intracellular $\mathrm{Ca}^{2+}$ increases, we examined the effects of several depolarizing agents on cAMP accumulation. Two other depolarizing agents, $\mathrm{K}_{2} \mathrm{SO}_{4}$ and veratridine, stimulated cAMP to levels comparable with $\mathrm{KCl}$ (Fig. $2 \mathrm{~A}$ ). Furthermore, stimulation of cAMP increases in DKO neurons was blocked by EGTA or BAPTA, indicating that the increase in cAMP depends on intracellular $\mathrm{Ca}^{2+}$ (Fig. 2 B). In contrast, thapsigargin pretreatment had no effect, suggesting that release of $\mathrm{Ca}^{2+}$ from intracellular pools is not responsible for the increased cAMP. Similarly, tetrodotoxin was without effect, indicating that activation of adenylyl cyclase was not attributable to stimulation of sodium channels or generation of electrical activity and action potentials. Collectively, these data indicate that increases in intracellular $\mathrm{Ca}^{2+}$ by depolarizing agents stimulates cAMP accumulation in neurons lacking the CaM-stimulated adenylyl cyclases. Approximately $40 \%$ of the total $\mathrm{Ca}^{2+}$-stimulated cAMP accumulation in hippocampal neurons is independent of $\mathrm{AC1}$ and AC8.

To determine whether $\mathrm{KCl}$-stimulated cAMP accumulation in DKO neurons is attributable to activation of $\mathrm{Ca}^{2+}$ channels, 


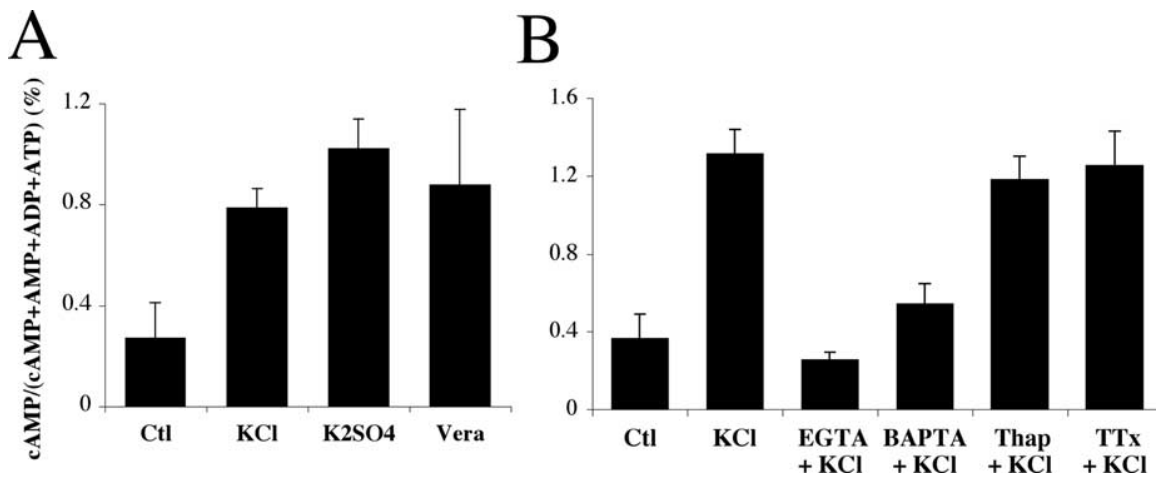

Figure 2. Stimulation of CAMP increases in DKO neurons by depolarizing agents depends on $\mathrm{Ca}^{2+}$ influx. $A, \mathrm{~K}_{2} \mathrm{SO}_{\text {, veratridine }}$ (Vera), or KCl stimulated cAMP levels in DKO hippocampal neurons. $\boldsymbol{B}$, EGTA or BAPTA-AM completely ablated the depolarizationinduced cAMP accumulation. Thapsigargin (Thap), an inhibitor of $\mathrm{Ca}^{2+}$-ATPase in the endoplasmic reticulum, and tetrodotoxin (TTX), an inhibitor of sodium channel and electrical activity, were without effect. Control (Ctl) samples were treated with Neurobasal medium containing the corresponding solvents for the inhibitors. Data are mean \pm SD of triplicates.

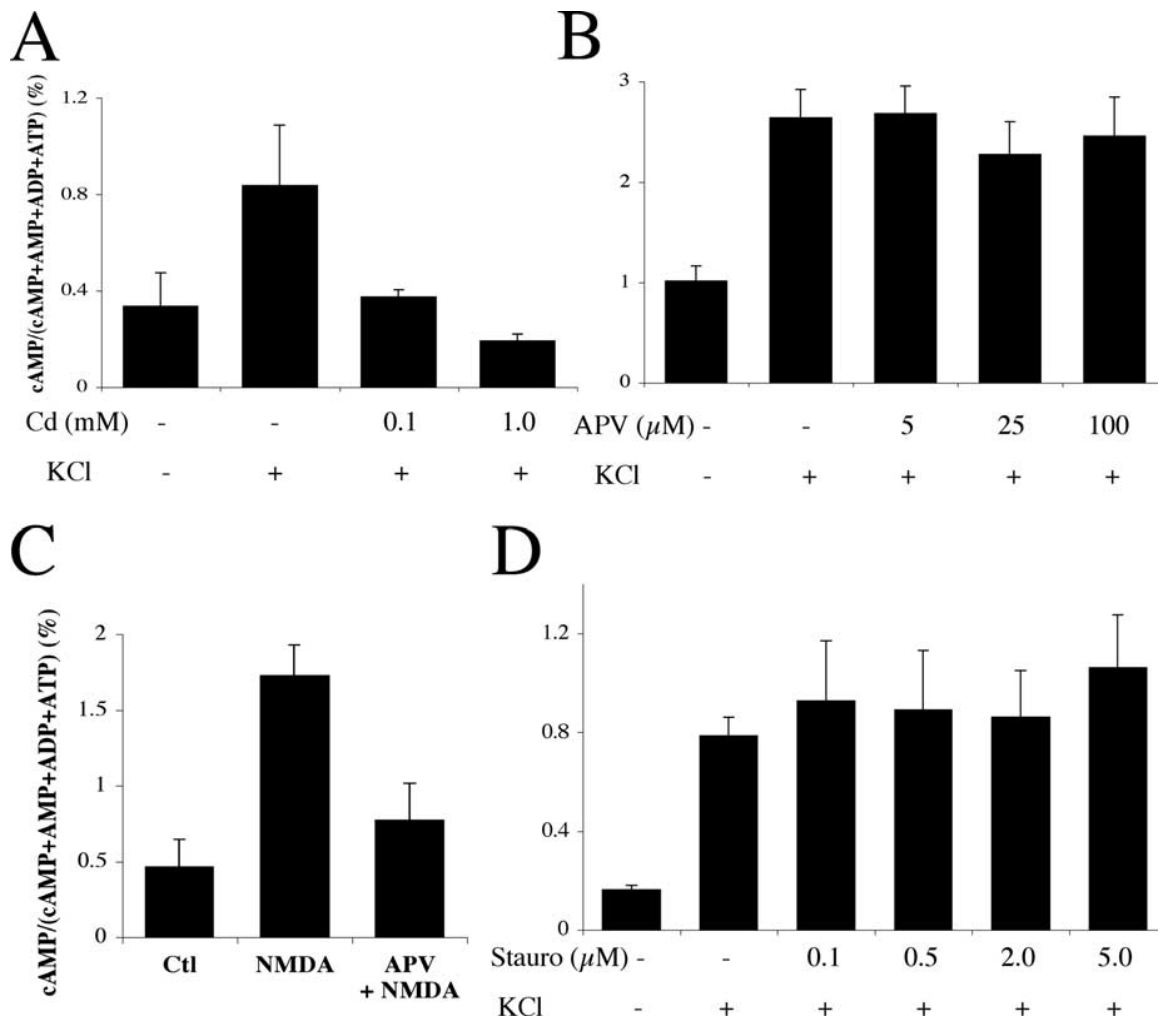

Figure 3. Stimulation of CAMP accumulation in DKO neurons by depolarizing agents depends on voltage-dependent $\mathrm{Ca}^{2+}$ channels. $\boldsymbol{A}, \boldsymbol{B}$, Cultured DKO hippocampal neurons were pretreated with various doses of $\mathrm{Cd}(\boldsymbol{A})$ or APV $(\boldsymbol{B})$, an inhibitor of the NMDA receptors, before stimulation with $50 \mathrm{~mm} \mathrm{KCl}$. $\boldsymbol{C}$, NMDA stimulation of CAMP increases in DKO neurons was blocked by pretreatment with APV. D, Pretreatment of DKO neurons with the general inhibitor of protein serine/threonine kinase, staurosporine (Stauro), did not affect KCl-stimulated cAMP accumulation. Control (Ctl) samples were treated with Neurobasal medium containing the corresponding solvents for the inhibitors. Data are mean \pm SD of triplicates.
This indicates that intracellular $\mathrm{Ca}^{2+}$ increases generated through activation of NMDA receptors can also increase cAMP in DKO neurons.

Formally, there are three general mechanisms for increasing cAMP levels in animal cells: activation of adenylyl cyclase, inhibition of PDE activity, or inhibition of cAMP release from the cell. However, the experiments described above were performed in high levels of PDE inhibitors. There are no known $\mathrm{Ca}^{2+}$-inhibited PDEs, and we detected no $\mathrm{Ca}^{2+}$-inhibited PDE activity in extracts from cultured hippocampal neurons. Furthermore, the levels of extracellular cAMP in the media from cultured hippocampal neurons is unaffected by $\mathrm{KCl}$ treatment (data not shown). Therefore, $\mathrm{Ca}^{2+}$ stimulation of intracellular cAMP levels in DKO neurons is most likely attributable to direct or indirect stimulation of adenylyl cyclase activity.

$\mathrm{Ca}^{2+}$ activation of adenylyl cyclase activity in neurons from DKO mice is not dependent on protein kinase activity Because protein kinases regulate the activities of several of the adenylyl cyclases (Hanoune and Defer, 2001), we examined the effect of staurosporine on $\mathrm{Ca}^{2+}$ stimulated cAMP accumulation in neurons from DKO mice. Staurosporine, a broad-spectrum protein kinase inhibitor, inhibits PKA, PKC, the CaM-dependent protein kinases and tyrosine kinases (Ruegg and Burgess, 1989). Pretreatment with staurosporine did not affect depolarization-induced cAMP accumulation in $\mathrm{DKO}$ neurons (Fig. 3D). Moreover, none of the specific inhibitors of PKCs or CAMK II affected $\mathrm{Ca}^{2+}$-stimulated cAMP in DKO neurons (supplemental Table 1, available at www.jneurosci.org as supplemental material). Specific inhibitors of MEK (MAP kinase kinase), p38, PI3 kinase, and JNK (c-Jun N-terminal protein kinase) were also without effect. These data suggest that depolarization-induced adenylyl cyclase activity in DKO hippocampal neurons is not mediated through a protein kinase. cadmium, $\mathrm{KCl}$ stimulation of cAMP levels was examined in the presence of cadmium, $\mathrm{Cd}^{2+}$, a general inhibitor of $\mathrm{Ca}^{2+}$ channels. $\mathrm{CdCl}_{2}$ at $0.1 \mathrm{~mm}$ completely blocked cAMP increases caused by $\mathrm{KCl}$ depolarization (Fig. $3 A$ ). Pretreatment of neurons with $\mathrm{APV}$, an NMDA receptor antagonist, did not affect the $\mathrm{KCl}$ induced cAMP accumulation, indicating that activation of NMDA receptors was not required (Fig. $3 B$ ). Furthermore, this suggests that neurotransmitter release does not contribute to the cAMP increase. Nevertheless, NMDA by itself caused an increase in CAMP in DKO neurons that was blocked by APV (Fig. 3C).
$\mathrm{Ca}^{2+}$ activation of adenylyl cyclase activity in neurons from DKO mice depends on protein phosphatase activity Pretreatment of DKO hippocampal neurons with the broadspectrum protein phosphatase inhibitor, okadaic acid, completely inhibited $\mathrm{Ca}^{2+}$ stimulation of adenylyl cyclase activity in DKO hippocampal neurons (Fig. 4A). Although endothall, a specific inhibitor of PP2A was without effect (Fig. $4 B$ ), cantharidin, an inhibitor of both PP2A and PP1 abrogated depolarizationinduced cAMP increases (Fig. $4 C$ ). This suggests the interesting possibility that hippocampal neurons have an alternative mech- 
anism for coupling $\mathrm{Ca}^{2+}$ to stimulation of adenylyl cyclase that depends on protein phosphatase activity. This finding also suggests that hippocampal neurons express a protein kinase-inhibited adenylyl cyclase activity that is activated when dephosphorylated by protein phosphatases. This hypothesis is supported by data showing that staurosporine treatment, by itself, enhanced cAMP levels in DKO neurons to an extent comparable with $\mathrm{KCl}$ (Fig. 5), whereas treatments with other reagents did not (supplemental Table 2, available at www.jneurosci.org as supplemental material).

\section{Calcineurin/PP2B is required for $\mathrm{Ca}^{2+}$}

\section{stimulation of adenylyl cyclase}

Because neither PP1 nor PP2A is directly stimulated by $\mathrm{Ca}^{2+}$, we considered the possibility that the $\mathrm{Ca}^{2+}$-activated phosphatase calcineurin (or PP2B) may play a role in the activation of adenylyl cyclase. Calcineurin was discovered as a $\mathrm{Ca}^{2+}$ / CaM-stimulated protein phosphatase (Wang and Desai, 1976) that is abundantly expressed in the hippocampus (Polli et al., 1991). Calcineurin activates PP1 by dephosphorylating inhibitor 1 (I-1), thereby causing the dissociation of I-1 from PP1 (Mulkey et al., 1994). Inhibitors of calcineurin including ascomycin, an analog of FK506 (Fig. 6A), and cyclosporine A (Fig. $6 B$ ) inhibited $\mathrm{Ca}^{2+}$ stimulation of cAMP levels in DKO neurons. This suggests that $\mathrm{Ca}^{2+}$ activation of calcineurin is required for $\mathrm{Ca}^{2+}$ stimulation of adenylyl cyclase in DKO neurons, either because it directly dephosphorylates adenylyl cyclase or because it activates PP1, which dephosphorylates adenylyl cyclase.

\section{Depolarization-induced cAMP production is markedly reduced in hippocampal neurons from calcineurin ${ }^{-/-}$mice} To directly test the hypothesis that neurons from the hippocampus express a calcineurin-stimulated adenylyl cyclase, hippocampal neurons from calcineurin ${ }^{-1-}$ mice were examined for cAMP accumulation (Fig. 7A). $\mathrm{Ca}^{2+}$-stimulated cAMP accumulation in neurons from calcineurin ${ }^{-1-}$ mice was approximately one-half of that seen in wild-type neurons (Fig. 7A), although the full complement of adenylyl cyclases responsive to $\mathrm{Ca}^{2+}$ and forskolin was expressed in hippocampal membranes (supplemental Fig. 1, available at www.jneurosci.org as supplemental material). Furthermore, the calcineurin inhibitor, cyclosporine $\mathrm{A}$, which partially inhibits $\mathrm{Ca}^{2+}$-stimulated adenylyl cyclase activity in wild-type neurons (Fig. $6 \mathrm{~B}$ ), did not affect this activity in calcineurin ${ }^{-1-}$ neurons (Fig. $7 B$ ).

\section{Discussion}

$\mathrm{Ca}^{2+}$ activation of adenylyl cyclases plays a critical role in the CNS by coupling activity-dependent increases in $\mathrm{Ca}^{2+}$ to stimulation of the cAMP signal transduction system (Wang and Storm, 2003). The effects of cAMP increases are mediated through PKA, cyclic nucleotide-gated ion channels, and other cAMP-binding proteins including cAMP-regulated guanylyl nucleotide exchange factors (Kawasaki et al., 1998). It has become increasingly evident that cross talk between cAMP signaling and other regulatory pathways may be particularly important for coincidence detection and that cAMP often serves as a "gate keeper" for other
B

C

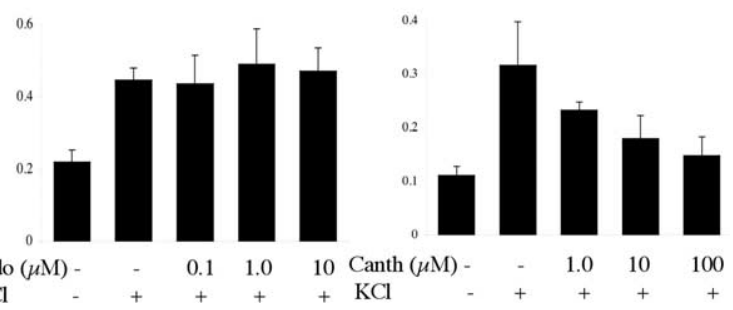

0.101 .00 Endo $(\mu \mathrm{M})$ -

$+\mathrm{KCl}$ ylyl cyclase in DKO neurons is dependent on phosphatase activity. Cultured neurons from the hippocampus of DKO newborn pups were pretreated with the protein phosphatase inhibitors before depolarization with $50 \mathrm{~mm} \mathrm{KCl}$. A, Okadaic acid (0kad), an inhibitor of PP1 and PP2A, blocked stimulation of adenylyl cyclase activity. $\boldsymbol{B}$, Endothall (Endo), an inhibitor of PP2A, was without effect. $\boldsymbol{C}$, Cantharidin (Canth), an inhibitor of PP2A and PP1, inhibited $\mathrm{KCl}$ stimulation of adenylyl cyclase. Control samples were treated with Neurobasal medium containing the corresponding solvents for the inhibitors. Data are mean \pm SD of triplicates.

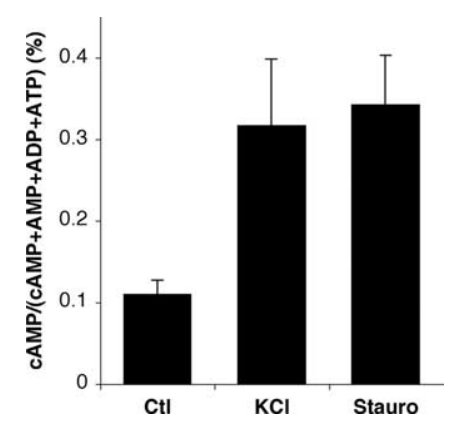

Figure 5. Adenylyl cyclase activity in DKO neurons is activated by a general inhibitor of protein kinases. Cultured neurons from the hippocampus of DKO newborn pups were treated with $10 \mu \mathrm{m}$ staurosporine (Stauro), $50 \mathrm{~mm} \mathrm{KCl}$ or buffer alone (Ctl) to determine intracellular cAMP accumulation, as described in Materials and Methods. Data are mean \pm SD of triplicates.

signaling events (Blitzer et al., 1998). For example, cross talk between extracellular signal-regulated protein kinase (ERK 1/2) and PKA is required for $\mathrm{Ca}^{2+}$ stimulation of the CREB (cAMPresponsive element-binding protein)/CRE transcriptional pathway in neurons because the nuclear translocation of ERK 1/2 requires activation of PKA (Impey et al., 1998). Furthermore, cAMP stimulates the activity of the ERK $1 / 2$ pathway in neurons (Vossler et al., 1997), whereas it inhibits signaling through the PI3 kinase pathway (Poser et al., 2003). Consequently, it is important to identify mechanisms for $\mathrm{Ca}^{2+}$ stimulation of intracellular cAMP in CNS neurons.

In this study, we discovered that hippocampal neurons lacking both of the CaM-stimulated adenylyl cyclases, AC1 and AC8, express $\mathrm{Ca}^{2+}$-stimulated adenylyl cyclase activity, which can be activated through voltage-sensitive $\mathrm{Ca}^{2+}$ channels or NMDA receptors. This adenylyl cyclase activity is insensitive to a broad range of protein kinase inhibitors but is blocked by inhibitors of calcineurin. Furthermore, hippocampal neurons from calcineurin $^{-1-}$ mice showed a significant reduction in $\mathrm{Ca}^{2+}$ stimulated adenylyl cyclase activity. The calcineurin-dependent cAMP increase is not a compensatory mechanism attributable to the absence of $\mathrm{AC} 1$ and AC8; phosphatase inhibitors also inhibited depolarization-induced cAMP increases in wild-type hippocampal neurons (supplemental Fig. 2, available at www. jneurosci.org as supplemental material). We conclude that there are two major mechanisms for coupling $\mathrm{Ca}^{2+}$ to cAMP in hippocampal neurons: a direct stimulation of $\mathrm{AC} 1$ and $\mathrm{AC} 8$ by $\mathrm{Ca}^{2+} / \mathrm{CaM}$ and a calcineurin-mediated process that is most likely attributable to the dephosphorylation of adenylyl cyclase or cal- 


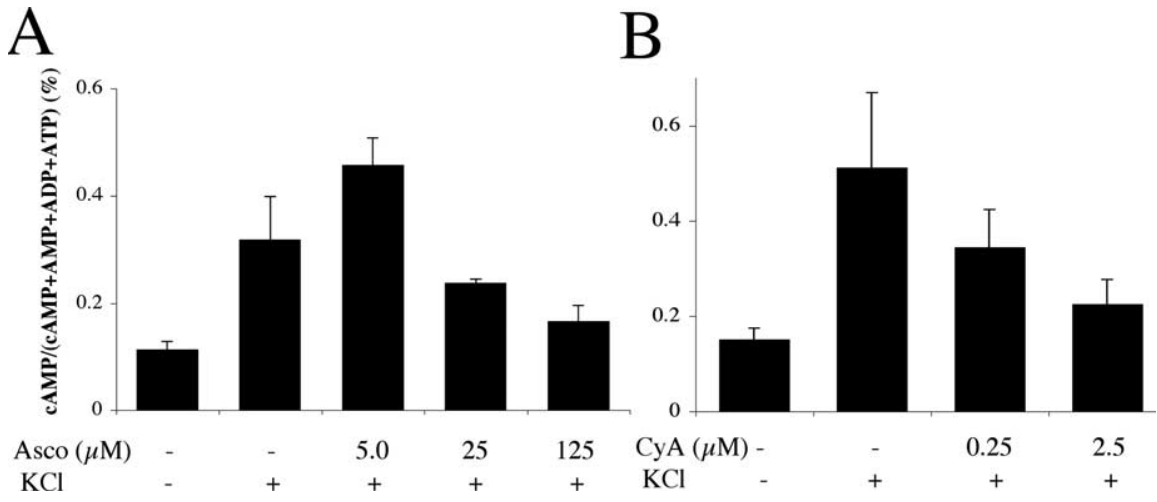

Figure 6. Depolarization-induced stimulation of adenylyl cyclase activity in DKO neurons is dependent on calcineurin activity. $\boldsymbol{A}, \boldsymbol{B}$, Cultured neurons from the hippocampus of DKO pups were pretreated with calcineurin inhibitors ascomycin $($ Asco; $\boldsymbol{A})$ or cyclosporine $\mathrm{A}(\mathrm{CyA} ; \boldsymbol{B})$ before depolarization with $50 \mathrm{~mm} \mathrm{KCl}$. Control samples were treated with Neurobasal medium containing solvent for the inhibitors. Data are mean \pm SD of triplicates.
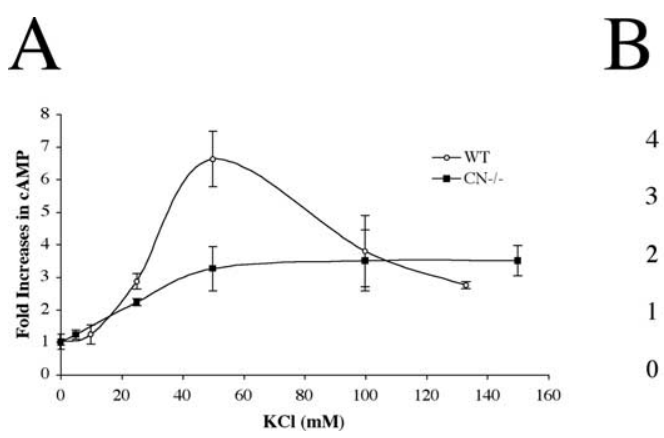

Figure 7. Cultured hippocampal neurons from calcineurin ${ }^{-1-}$ mice show reduced $\mathrm{Ca}^{2+}$-stimulated adenylyl cyclase activity. $A$, Primary neurons established from calcineurin ${ }^{-/-}\left(\mathrm{CN}^{-/-}\right)$or WT mice were maintained in culture for $12-14 \mathrm{~d}$ before treatment with increasing concentrations of $\mathrm{KCl}$. B, Calcineurin ${ }^{-1-}$ hippocampal neurons were pretreated with $50 \mu \mathrm{m}$ cyclosporine $\mathrm{A}(\mathrm{CyA})$, an inhibitor of calcineurin, for $75 \mathrm{~min}$ before $\mathrm{KCl}$ treatment. Control samples were treated with Neurobasal medium containing solvent for the inhibitors. Data are mean \pm SD of triplicates.

cineurin activation of another protein that stimulates adenylyl cyclase, e.g., PP1.

It has been reported that forebrain expresses a calcineurininhibited adenylyl cyclase, AC9 (Antoni et al., 1998). If AC9 were a major component of adenylyl cyclase activity in the hippocampus, one would expect that calcineurin ${ }^{-/-}$mice would show enhanced adenylyl cyclase activity in the presence of increased intracellular $\mathrm{Ca}^{2+}$ compared with wild-type mice. The fact that $\mathrm{Ca}^{2+}$-activated adenylyl cyclase activity is greatly decreased in hippocampal neurons from calcineurin ${ }^{-1-}$ mice argues that $\mathrm{Ca}^{2+}$ inhibition of AC9 does not play a major signaling role in hippocampal neurons.

What is the physiological significance of calcineurinstimulated adenylyl cyclase activity in hippocampal neurons? Calcineurin has been implicated in several forms of neuroplasticity, including LTD (Mulkey et al., 1994), memory formation (Zeng et al., 2001), and extinction of fear memory (Lin et al., 2003). For example, the same mutant animals used in this study, which have a forebrain-specific disruption of the calcineurin regulatory subunit gene locus, have impaired Schaffer collateral/ CA1 LTD and are defective in working/episodic memory in the Morris water maze and in the eight-arm radial maze (Zeng et al., 2001). These mice also display several behavioral abnormalities reminiscent of schizophrenic patients, including increased locomotor activity and decreased social interactions (Miyakawa et al., 2003).
$\mathrm{Ca}^{2+}$ activation of calcineurin may affect synaptic plasticity in a number of ways, including downregulation of NMDA receptor currents (Shi et al., 2000), activation of PP1, inhibition of dynamin I GTPase activity (Liu et al., 1994), and dephosphorylation of neuromodulin, the latter of which may control free CaM levels (Liu and Storm, 1989; Liu and Storm, 1990). The data reported in this study suggest the interesting possibility that loss of calcineurin-stimulated adenylyl cyclase activity may also contribute to some of the electrophysiological and behavioral phenotypes exhibited by calcineurin ${ }^{-1-}$ mice. Because LTD depends on PKA signaling (Brandon et al., 1995; Tzounopoulos et al., 1998), calcineurin-stimulated adenylyl cyclase activity may provide a critical cAMP signal required to support LTD as well as other neuronal processes. In addition, the schizophrenic-like phenotype observed with calcineurin $^{-1-}$ mice may be attributable to decreases in $\mathrm{Ca}^{2+}$ coupling to cAMP (Garver et al., 1982; Dean et al., 1997). Although we did not demonstrate that calcineurin activates adenylyl cyclase activity in brain in vivo, the fact that a variety of events that depend on cAMP signaling are compromised in calcineurin $^{-/-}$mice supports this hypothesis.

In summary, we discovered a novel mechanism for coupling of activitydependent $\mathrm{Ca}^{2+}$ increases to cAMP in hippocampal neurons. Calcineurin activation of adenylyl cyclase activity in hippocampal neurons may contribute to several forms of neuroplasticity, including LTD and some forms of learning and memory.

\section{References}

Abel T, Nguyen PV, Barad M, Deuel TAS, Kandel ER (1997) Genetic demonstration of a role for PKA in the late phase of LTP and in hippocampusbased long-term memory. Cell 88:615-626.

Antoni FA, Palkovits M, Simpson J, Smith SM, Leitch AL, Rosie R, Fink G, Paterson JM (1998) $\mathrm{Ca}^{2+} /$ calcineurin-inhibited adenylyl cyclase, highly abundant in forebrain regions, is important for learning and memory. J Neurosci 18:9650-9661.

Blitzer RD, Conner JH, Brown GP, Wong T, Shenolikar S, Iyengar R, Landau EM (1998) Gating of CaMKII by cAMP-regulated protein phosphatase activity during LTP. Science 280:1940-1943.

Brandon EP, Zhuo M, Huang YY, Qi M, Gerhold KA, Burton KA, Kandel ER, McKnight GS, Idzerda RL (1995) Hippocampal long-term depression and depotentiation are defective in mice carrying a targeted disruption of the gene encoding the RI beta subunit of cAMP-dependent protein kinase. Proc Natl Acad Sci USA 92:8851-8855.

Chan GC, Lernmark U, Xia Z, Storm DR (2001) DNA elements of the type 1 adenylyl cyclase gene locus enhance reporter gene expression in neurons and pinealocytes. Eur J Neurosci 13:2054-2066.

Choi EJ, Wong ST, Dittman AH, Storm DR (1993) Phorbol ester stimulation of the type I and type III adenylyl cyclases in whole cells. Biochemistry 32:1891-1894.

Dean B, Opeskin K, Pavey G, Hill C, Keks N (1997) Changes in protein kinase $\mathrm{C}$ and adenylate cyclase in the temporal lobe from subjects with schizophrenia. J Neural Transm 104:1371-1381.

Frey U, Reymann KG, Matthies H (1991) The effect of dopaminergic D1 
receptor blockade during tetanization on the expression of long-term potentiation in the rat CA1 region in vitro. Neurosci Lett 129:111-114.

Frey U, Huang YY, Kandel ER (1993) Effects of cAMP simulate a late stage of LTP in hippocampal CA1 neurons. Science 260:1661-1664.

Garver DL, Johnson C, Kanter DR (1982) Schizophrenia and reduced cyclic AMP production: evidence for the role of receptor-linked events. Life Sci 31:1987-1992.

Hanoune J, Defer N (2001) Regulation and role of adenylyl cyclase isoforms. Annu Rev Pharmacol Toxicol 41:145-174.

Huang YY, Kandel ER, Varshavsky L, Brandon EP, Qi M, Idzerda RL, McKnight GS, Bourtchouladze R (1995) A genetic test of the effects of mutations in PKA on mossy fiber LTP and its relation to spatial and contextual learning. Cell 83:1211-1222.

Impey S, Mark M, Villacres EC, Poser S, Chavkin C, Storm DR (1996) Induction of CRE-mediated gene expression by stimuli that generate longlasting LTP in area CA1 of the hippocampus. Neuron 16:973-982.

Impey S, Obrietan K, Wong ST, Poser S, Yano S, Wayman G, Deloulme JC, Chan G, Storm DR (1998) Cross talk between ERK and PKA is required for $\mathrm{Ca}^{2+}$ stimulation of CREB-dependent transcription and ERK nuclear translocation. Neuron 21:869-883.

Jacobowitz O, Chen J, Premont RT, Iyengar R (1993) Stimulation of specific types of Gs-stimulated adenylyl cyclases by phorbol ester treatment. J Biol Chem 268:3829-3832.

Kawabe J, Ebina T, Toya Y, Oka N, Schwencke C, Duzic E, Ishikawa Y (1996) Regulation of type $\mathrm{V}$ adenylyl cyclase by PMA-sensitive and-insensitive protein kinase C isoenzymes in intact cells. FEBS Lett 384:273-276.

Kawasaki H, Springett GM, Mochizuki N, Toki S, Nakaya M, Matsuda M, Housman DE, Graybiel AM (1998) A family of cAMP-binding proteins that directly activate Rap1. Science 282:2275-2279.

Lin CH, Yeh SH, Leu TH, Chang WC, Wang ST, Gean PW (2003) Identification of calcineurin as a key signal in the extinction of fear memory. J Neurosci 23:1574-1579.

Liu JP, Sim AT, Robinson PJ (1994) Calcineurin inhibition of dynamin I GTPase activity coupled to nerve terminal depolarization. Science 265:970-973.

Liu YC, Storm DR (1989) Dephosphorylation of neuromodulin by calcineurin. J Biol Chem 264:12800-12804.

Liu YC, Storm DR (1990) Regulation of free calmodulin levels by neuromodulin: neuron growth and regeneration. Trends Pharmacol Sci 11:107-111.

Miyakawa T, Leiter LM, Gerber DJ, Gainetdinov RR, Sotnikova TD, Zeng H, Caron MG, Tonegawa S (2003) Conditional calcineurin knockout mice exhibit multiple abnormal behaviors related to schizophrenia. Proc Natl Acad Sci USA 100:8987-8992.

Mulkey RM, Endo S, Shenolikar S, Malenka RC (1994) Involvement of a calcineurin/inhibitor-1 phosphatase cascade in hippocampal long-term depression. Nature 369:486-488.

Nguyen PV, Kandel ER (1996) A macromolecular synthesis-dependent late phase of long-term potentiation requiring cAMP in the medial perforant pathway of rat hippocampal slices. J Neurosci 16:3189-3198.
Polli JW, Billingsley ML, Kincaid RL (1991) Expression of the calmodulindependent protein phosphatase, calcineurin, in rat brain: developmental patterns and the role of nigrostriatal innervation. Brain Res Dev Brain Res 63:105-119.

Poser S, Storm DR (2001) Role of $\mathrm{Ca}^{2+}$-stimulated adenylyl cyclases in LTP and memory formation. Int J Dev Neurosci 19:387-394.

Poser S, Impey S, Xia Z, Storm DR (2003) Brain-derived neurotrophic factor protection of cortical neurons from serum withdrawal-induced apoptosis is inhibited by cAMP. J Neurosci 23:4420-4427.

Ruegg UT, Burgess GM (1989) Staurosporine, K-252 and UCN-01: potent but nonspecific inhibitors of protein kinases. Trends Pharmacol Sci 10:218-220.

Salomon Y (1991) Cellular responsiveness to hormones and neurotransmitters: conversion of $[3 \mathrm{H}]$ adenine to $[3 \mathrm{H}]$ cAMP in cell monolayers, cell suspensions, and tissue slices. Methods Enzymol 195:22-28.

Shi J, Townsend M, Constantine-Paton M (2000) Activity-dependent induction of tonic calcineurin activity mediates a rapid developmental downregulation of NMDA receptor currents. Neuron 28:103-114.

Storm DR, Hansel C, Hacker B, Parent A, Linden DJ (1998) Impaired cerebellar LTP in type I adenylyl cyclase mutant mice. Neuron 20:1199-1210.

Tzounopoulos T, Janz R, Sudhof TC, Nicoll RA, Malenka RC (1998) A role for cAMP in long-term depression at hippocampal mossy fiber synapses. Neuron 21:837-845.

Villacres EC, Wong ST, Chavkin C, Storm DR (1998) Type I adenylyl cyclase mutant mice have impaired mossy fiber long-term potentiation. J Neurosci 18:3186-3194.

Vossler MR, Yao H, York RD, Pan MG, Rim CS, Stork PJ (1997) cAMP activates MAP kinase and Elk-1 through a B-Raf- and Rap1-dependent pathway. Cell 89:73-82.

Wang H, Storm DR (2003) Calmodulin-regulated adenylyl cyclases: crosstalk and plasticity in the central nervous system. Mol Pharmacol 63:463-468.

Wang H, Ferguson GD, Pineda VV, Storm DR (2004) A genetic increase in type I adenylyl cyclase in mouse brain enhances LTP and recognition memory. Nat Neurosci 7:635-642.

Wang JH, Desai R (1976) A brain protein and its effect on the $\mathrm{Ca}^{2+}$ - and protein modulator-activated cyclic nucleotide phosphodiesterase. Biochem Biophys Res Commun 72:926-937.

Wong ST, Athos J, Figueroa XA, Pineda VV, Schaefer ML, Chavkin CC, Muglia LJ, Storm DR (1999) Calcium-stimulated adenylyl cyclase activity is critical for hippocampus dependent long-term memory and latephase LTP. Neuron 23:787-798.

Wu ZL, Thomas SA, Villacres EC, Xia Z, Simmons ML, Chavkin C, Palmiter $\mathrm{RD}$, Storm DR (1995) Altered behavior and long-term potentiation in type I adenylyl cyclase mutant mice. Proc Natl Acad Sci USA 92:220-224.

Zeng H, Chattarji S, Barbarosie M, Rondi-Reig L, Philpot BD, Miyakawa T, Bear MF, Tonegawa S (2001) Forebrain-specific calcineurin knockout selectively impairs bidirectional synaptic plasticity and working/episodiclike memory. Cell 107:617-629. 